\title{
Dafna Langgut, Oded Lipschitz. "Dry climate during the early Persian period and its impact on the establishement of Idumea"
}

\section{Astrid Nunn}

\author{
(2) OpenEdition \\ Journals \\ Édition électronique \\ URL : http://journals.openedition.org/abstractairanica/48416 \\ DOI : $10.4000 /$ abstractairanica. 48416 \\ ISBN : 1961-960X \\ ISSN : 1961-960X \\ Éditeur : \\ CNRS (UMR 7528 Mondes iraniens et indiens), Éditions de l'IFRI
}

\section{Référence électronique}

Astrid Nunn, « Dafna Langgut, Oded Lipschitz. "Dry climate during the early Persian period and its impact on the establishement of Idumea" », Abstracta Iranica [En ligne], Volume 40-41 | 2019, document 37, mis en ligne le 15 juillet 2019, consulté le 27 avril 2021. URL : http://

journals.openedition.org/abstractairanica/48416; DOI : https://doi.org/10.4000/abstractairanica 48416

Ce document a été généré automatiquement le 27 avril 2021.

Tous droits réservés 


\title{
Dafna Langgut, Oded Lipschitz. "Dry climate during the early Persian period and its impact on the establishement of Idumea"
}

\author{
Astrid Nunn
}

\section{RÉFÉRENCE}

Dafna Langgut, Oded Lipschitz. "Dry climate during the early Persian period and its impact on the establishement of Idumea", Transeuphratène 49, 2017, p. 135-162

$1 \quad \mathrm{Au}$ VIII ${ }^{\mathrm{ème}}$ et VII ${ }^{\text {ème }}$ s. (Late First Temple Period) le royaume de Judée s'étendait jusqu'à Bersheba et Arad, incluant ainsi des populations édomites et arabes. La royauté de Judée est impuissante à partir de la conquête de Nabuchodonozor en 597 av. J.-C. Petit à petit ses zones marginales du sud se vident, suivi d'une migration de ses habitants vers le cœur de la province de Yehud. En conséquence, la frontière commune entre la Judée et l'Idumée se déplace vers le nord au IV ${ }^{\text {ème }} s$.

2 L'explication "classique" de cette migration est politique. Les A. disposent toutefois d'analyses de pollens qui indiquent un assèchement climatique. Selon eux, cette migration a été causée par un assèchement survenu vers la fin du VIème et la première moitié du Vème s. en Judée du Sud. Le vide provoqué par le départ des habitants de Yehud aurait été comblé par des groupes nomades ce qui déplaça la frontière septentrionale de l'Idumée vers le nord. Les conditions climatiques redevinrent plus humides en Idumée au début de l'époque hellénistique, provoquant une intensification de l'agriculture, tout particulièrement de celle de l'olivier. 


\section{AUTEURS}

\section{ASTRID NUNN}

Université de Munich 